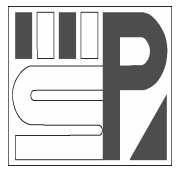

Science Press
Journal of Arid Land

2012, 4(1): 29-35

doi: 10.3724/SP.J.1227.2012.00029

jal.xjegi.com; www.chinasciencejournal.com

\title{
Impacts of livestock grazing on a savanna grassland in Kenya
}

\author{
John $\mathrm{KIOKO}^{1 *}$, John Warui KIRINGE${ }^{1}$, Simon Ole SENO² \\ ${ }^{1}$ The School for Field Studies, Center for Wildlife Management Studies, Nairobi 27743 - 00506, Kenya; \\ ${ }^{2}$ School of Natural Resources Management, Narok University College, Narok 861-20500, Kenya
}

\begin{abstract}
The dynamics of most rangelands in Kenya remain to be poorly understood. This paper provides baseline information on the response of a semiarid rangeland under different livestock grazing regimes on land inhabited by the Massai people in the east side of Amboseli National Park in Kenya. The data were collected from grasslands designated into four types: (1) grassland from previous Massai settlements that had been abandoned for over twenty years; (2) grassland excluded from livestock grazing for eight years; (3) a dry season grazing area; and (4) a continuous grazing area where grazing occurred throughout all seasons. Collected data included grass species composition, grass height, inter-tuft distance, standing grass biomass and soil characteristics. The results indicated that continuous grazing area in semiarid rangelands exhibited loss of vegetation with negative, long-term effects on grass functional qualities and forage production, whereas grassland that used traditional Maasai grazing methods showed efficiency and desirable effects on the rangelands. The results also showed that abandoned homestead sites, though degraded, were important nutrient reservoirs.
\end{abstract}

Keywords: dry season grazing; grass species composition; livestock grazing; soil nutrients; Kenya

Pastoralists such as the Maasai of East Africa adapted to life in arid lands by designating wet and dry season grazing areas (Berger, 1993). Their use of the rangelands was based on mobility, splitting and dispersing livestock over the landscape during wet and dry seasons (Oba et al., 2000), to ensure limited dry concentrated continuous grazing. The sphere of the Maasai in Kenya and Tanzania is continually experiencing dramatic changes in land tenure and land use, with broad consequences on the rangeland dynamics. The Maasai have progressively lost some of their grazing land to competitive use such as crop farming (Campbell et al., 2000) through the establishment of wildlife protection areas (Western and Wright, 1994). In Kenya, the Massai land was transformed from communal into group ranches in the 1960s (Graham, 1989). Group ranches are large parcels of land that were demarcated under the Land Adjudication Act of 1968 (Cap 284) and legally registered to one group duly constituted under the Land (Group Representatives) Act of 1968 (Cap 287). This further reduced the movement of Maasai livestock by largely confining them into group ranches. Under increased pressure from the group ranch members, who wanted to own individual parcels of land, the trend is now towards subdivision of the group ranches, further transforming the land use from extensive seasonal grazing to continuous grazing, and intensive livestock grazing (Burnsilver and Mwangi, 2007).

The savannahs, home of African rangelands, are highly dynamic systems due to factors such as rainfall, soil nutrient levels, fire and herbivory (Skarpe, 1992). Livestock herbivory can cause shifts in plant species composition by replacing highly palatable grasses with unpalatable species (Owen-Smith, 1999). In the semiarid savannas of East Africa, there is consistent evidence of change in species along grazing gradients, often characterized by a reduction in tuft size and replacement of perennial grasses by annual grasses (O'Connor and Pickett, 1999). The response of grass

Received 2011-06-23; accepted 2011-08-22

*Corresponding author: John KIOKO (E-mail: jkioko@fieldstudies.org) 
species response to grazing is important in determining grazing capacity (the average number of animals that can be supported by an area) (Galt et al., 2000). Three categories of grasses, i.e. Decreaser, Increaser I and Increaser II describe the status of the rangeland (Trollope, 1990). Decreaser species dominate ranges in good condition and decrease with over or undergrazing. Increaser I species dominate in undergrazed or selectively utilized rangelands, and Increaser II species dominate in rangelands that are overgrazed. Under better management, heavily utilized rangelands that indicate overgrazing by the existence of Increaser II species can shift to a dominance of more palatable Decreaser species (Botha, 1999).

The inter-tuft distance can be used as an index of soil erosion potential (Trollope and Trollope, 1999). As vegetation cover declines, soil erosion increases, generating negative consequences on rangeland productivity (Oudtshoorn, 1992). Due to severe grazing, a reduction in plant biomass leads to soil loss that depletes the existing nutrients of soil, resulting in the reduction of soil fertility (Morgan, 1995).

A collapse of the traditional Maasai grazing system is hypothesized to have negative effects on the rangeland, likely leading to an increase in land degradation. This hypothesis was tested by comparing the vegetation functional characteristics in the areas grazed con- tinuously, regardless of seasonality, with those in the areas excluded from livestock grazing for an eightyear period, grazed only during the dry season, and past Massai settlements that had been abandoned for over twenty years.

\section{Study area and methods}

The study area is in the southern Maasailand of Kenya (Fig. 1). It covers $251 \mathrm{~km}^{2}$, and is located in $02^{\circ} 69^{\prime} \mathrm{S}-02^{\circ} 77^{\prime} \mathrm{S}$ and $37^{\circ} 41^{\prime} \mathrm{E}-37^{\circ} 38^{\prime} \mathrm{E}$, to the east of Amboseli National Park. The area is semiarid, in agro-climate zone VI (Pratt and Gwynne, 1978). The rain seasons exhibited bimodal seasonality, with short, light rain in the dry season that occurred between November and December, and long, heavy rain in the wet season between March and May (Musembi, 1986). The rainfall was low (about $500 \mathrm{~mm}$ per year), often variable and poorly distributed. The temperatures for the area fluctuated between $14^{\circ} \mathrm{C}$ and $30^{\circ} \mathrm{C}$ (Katampoi et al., 1990). The soils were young and undeveloped black cotton soils that were poor in nutrients and susceptible to erosion (Katampoi et al., 1990). Black cotton soils dominated the flood plains, while the well-drained higher elevations had calcareous and sandy loams. The vegetation was classified as wooded and bushed grassland, grassland and dwarf shrub

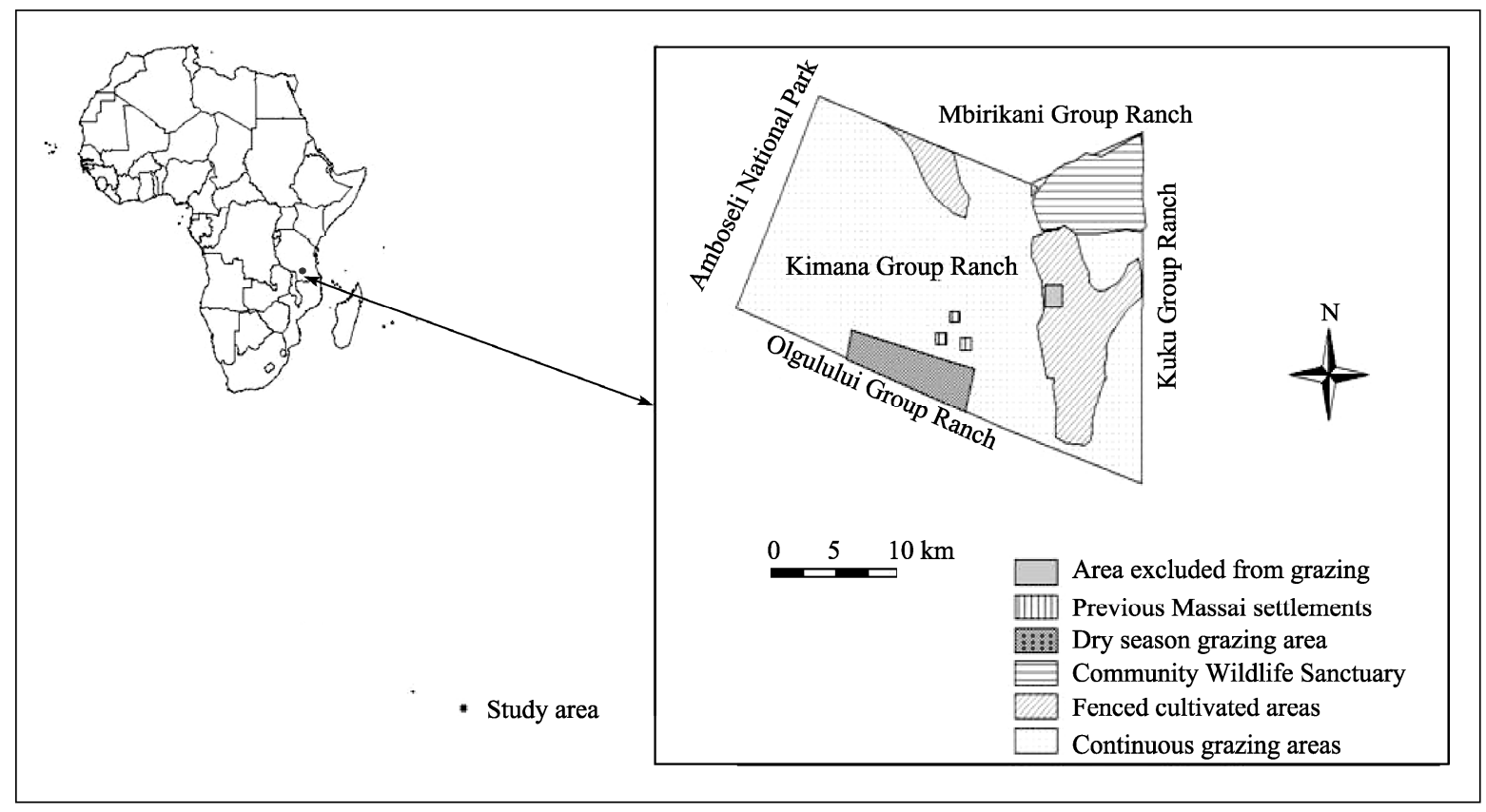

Fig. 1 Location of the study area in relation to Amboseli National Park 
grassland (Pratt and Gwynne, 1978). The area is predominantly important for wildlife conservation and livestock grazing for the Maasai people.

\subsection{Data collection}

Four types of sites were chosen. They included: (1) previous Maasai settlement areas ( about $3 \mathrm{~km}^{2}$ ) that had been abandoned for over twenty years; (2) an area excluded from livestock grazing for eight years (about $5 \mathrm{~km}^{2}$ ); (3) a dry season/calf grazing area (about $4 \mathrm{~km}^{2}$ ) and (4) a livestock area under continuous grazing (6 $\mathrm{km}^{2}$ ). The sites experienced similar rainfall and soil conditions.

The Descending Step Point Method (Mentis, 1981; Trollope and Trollope, 1999) was used to assess vegetation functional characteristics. In each site, five transects in 200-m length with varying widths were established. The data of soil erosion potential, grass biomass, grass species composition and grass height were collected along each transect, with an interval of two meters. The soil erosion potential was determined by measuring the distance from transect to the base of the nearest grass species. To estimate the grass biomass, the Disc Pasture Meter Method (Bransby and Tainton, 1977) was used.

The ability of each grass in producing forage for livestock grazing was assigned a forage score ranging from 0 to 10 . The forage potential was determined using the method by Trollope and Trollope (1999).

The status of soil nutrients was determined in each study site. Soil samples were collected at $10-\mathrm{cm}$ intervals, in 30-cm depth from six random locations within each site. Analysis of soil $\mathrm{pH}, \mathrm{Ca}, \mathrm{Mg}, \mathrm{K}, \mathrm{C}$ and $\mathrm{N}$ was undertaken at the International Centre for Research in Agro-Forestry (ICRAF) Laboratories, Nairobi, Kenya.

\subsection{Data analyses}

A Chi-Square Goodness of Fit test was used to determine differences in the occurrence of grass species, forage scores and total bare ground among the study sites. A one-way analysis of variance (ANOVA) test was used to compare the mean inter-tuft distances and mean grass heights among the study sites. A Tukey's HSD test was then carried out to determine which sites differed significantly from the others. The mean disc pasture meter height for each site was used to calculate the site's grass biomass based on:

$$
Y=-3340+2323 \sqrt{X} \text {. }
$$

Where $Y$ is the weight of grass $\left(\mathrm{kg} / \mathrm{hm}^{2}\right)$, and $X$ is the disc pasture meter height $(\mathrm{cm})$. The values come from work undertaken in similar rangelands in northern Kenya (Botha, 1999). The Kruskal-Wallis test was used to test whether there were variations in the amounts of soil parameters across the sites.

\section{Results}

\subsection{Species composition and grass ecological status}

Fifteen grass species were found in the study area (Table 1). The area was mostly dominated by Increaser I grass species-Pennisetum stramenium and Pennisetum mezianum and Increaser II grass species-Cynodon dactylon. Cenchrus ciliaris, Panicum maximum and Themenda triandra were the only three Decreaser species recorded.

There were significant differences in the occurrences of the three ecological grass categories in each of the study sites (Table 2). Most of the study sites were dominated by Increaser I and Increaser II grass species.

\subsection{Grass height, inter-tuft distance and standing biomass}

The grass height differed significantly among the study sites $(P<0.001)$. The average grass height was $40.68 \pm 1.24 \mathrm{~cm}($ mean \pm SE) in the site that excluded from grazing for an eight-year period, $1.17 \pm 0.15 \mathrm{~cm}$ in the sites previously settled by the Maasai people over twenty years ago, $31.53 \pm 0.74 \mathrm{~cm}$ in the dry season grazing area and $4.29 \pm 0.16 \mathrm{~cm}$ in the continuous grazing area.

The mean inter-tuft distance varied across the study sites $(P<0.001)$. The continuous grazing area had the highest inter-tuft distance $(69.11 \pm 0.62 \mathrm{~cm})$, while the area excluded from livestock grazing for eight years had the least inter-tuft distance $(22.53 \pm 0.86 \mathrm{~cm})$. The total occurrence of bare ground was significantly different between the four sites $(P<0.001)$. The dry season grazing area and the continuous grazing area had the largest bare ground, $35.43 \pm 0.37 \mathrm{~cm}$ and $49.81 \pm 21 \mathrm{~cm}$, respectively, compared to the area previously settled by the Maasai people $(1.84 \pm 18 \mathrm{~cm})$, and the areas excluded from livestock grazing for at least eight years $(12.33 \pm 49 \mathrm{~cm})$.

The total grass biomass differed significantly between the dry season grazing area, the area excluded 
from livestock grazing and the previously settled Maasai areas $(P<0.001)$, but was not significantly different between the dry season grazing area $(5,639.94$ $\left.\mathrm{kg} / \mathrm{hm}^{2}\right)$ and the area excluded from livestock grazing $\left(5,350.00 \mathrm{~kg} / \mathrm{hm}^{2}\right)(P=1.00)$. The previous Maasai settlements had $108.62 \mathrm{~kg} / \mathrm{hm}^{2}$. Since most of the continuous grazing areas were bare ground, the disc height value $(0.74 \pm 0.20 \mathrm{~cm})$ was not considered in grass biomass calculation.

\subsection{Forage potential}

The scores for total forage biomass were different between the four study sites $(P<0.001)$. However, the dry season grazing area and the area excluded from livestock grazing had similar grazing values, 467 and 444 , respectively $(P=0.446)$. The sites with the lowest forage potential were the previous Maasai settlements and the continuous grazing area, with values of 224 and 48 , respectively.

\subsection{Soil properties}

The measured values for soil properties showed that there were significant differences between the study sites (Table 3). The mean contents of exchangeable calcium, total carbon, total nitrogen, exchangeable magnesium and exchangeable potassium were highest in the previous Maasai settlements. The continuous grazing area had the lowest mean contents of exchangeable calcium, total nitrogen, and a lower $\mathrm{pH}$ value, while the area excluded from grazing had a higher $\mathrm{pH}$ value.

\section{Discussion}

The results showed that continuous grazing had undesirable effects on the rangeland, impairing functional characteristics of plants. The savannahs are dynamic systems where spatio-temporal variability of abiotic

Table 1 Frequency of occurrence of grass species across study sites

\begin{tabular}{|c|c|c|c|c|c|}
\hline \multirow[t]{2}{*}{ Species } & $\begin{array}{c}\text { Grass ecological } \\
\text { category }\end{array}$ & $\begin{array}{l}\text { Exclosure area } \\
\qquad(n=704)\end{array}$ & $\begin{array}{c}\text { Maasai settle- } \\
\text { ments } \\
(n=784)\end{array}$ & $\begin{array}{c}\text { Dry season grazing area } \\
\text { (Olopololi) } \\
(n=960)\end{array}$ & $\begin{array}{c}\text { Continuous } \\
\text { grazing area } \\
\quad(n=96)\end{array}$ \\
\hline & \multicolumn{5}{|c|}{$(\%)$} \\
\hline Panicum maximum & Decreaser & 0.15 & 0.00 & 0.00 & 0.00 \\
\hline Themeda triandra & Decreaser & 0.15 & 0.00 & 0.15 & 0.00 \\
\hline Cenchrus ciliaris & Decreaser & 20.37 & 0.00 & 1.12 & 1.34 \\
\hline Pennisetum stramenium & Increaser 1 & 36.88 & 5.06 & 63.13 & 56.70 \\
\hline Pennisetum mezianum & Increaser 1 & 0.28 & 0.23 & 4.44 & 12.46 \\
\hline Cynodon dactylon & Increaser 11 & 35.31 & 93.99 & 22.25 & 20.31 \\
\hline Digitaria scalarum & Increaser 11 & 3.00 & 0.00 & 1.42 & 2.24 \\
\hline Chloris roxburghiana & Increaser 11 & 0.57 & 0.00 & 0.00 & 0.13 \\
\hline Aristida kenyensis & Increaser 11 & 1.00 & 0.00 & 0.48 & 5.40 \\
\hline Brachiaria sp. & Increaser 11 & 0.72 & 0.59 & 2.38 & 0.26 \\
\hline Harpachne schimperii & Increaser 11 & 0.43 & 0.00 & 0.63 & 0.48 \\
\hline Setaria verticilata & Increaser 11 & 0.43 & 0.00 & 0.00 & 0.00 \\
\hline Dactyloctenium aegyptium & Increaser 11 & 0.28 & 0.00 & 0.00 & 0.27 \\
\hline Eragrostis tenuifolia & Increaser 11 & 0.28 & 0.00 & 3.35 & 0.42 \\
\hline Sporobolus fimbriatus & Increaser 11 & 0.14 & 0.12 & 0.63 & 0.00 \\
\hline
\end{tabular}

Table 2 Occurrence of different grass species in different study sites

\begin{tabular}{ccccc}
\hline $\begin{array}{c}\text { Grass ecological } \\
\text { category }\end{array}$ & $\begin{array}{c}\text { Area excluded from live- } \\
\text { stock grazing }\end{array}$ & $\begin{array}{c}\text { Previous Maasai settlement } \\
\text { area }\end{array}$ & Dry season/calf grazing area & Continuous grazing area \\
\hline Decreaser & 143 & 0 & 11 & 1 \\
Increaser 1 & 262 & 46 & 651 & 65 \\
Increaser 11 & 298 & 743 & 299 & 28 \\
$\chi^{2}$ test & $\chi^{2}=56.16, \mathrm{df}=2, P<0.001$ & $\chi^{2}=631.17, P<0.001$ & $\chi^{2}=641.46, \mathrm{df}=2, P<0.001$ & $\chi^{2}=65.89, \mathrm{df}=2, P<0.001$ \\
\hline
\end{tabular}


Table 3 Kruskal-Wallis $\mathrm{H}$ test results for soil parameters in different study sites

\begin{tabular}{|c|c|c|c|c|c|c|c|}
\hline Study sites & $\mathrm{pH}$ & $\begin{array}{l}\text { Exchangeable } \\
\text { acidity } \\
\text { (me/100g soil) }\end{array}$ & $\begin{array}{l}\text { Exchangeable } \\
\text { calcium } \\
\text { (me/100g soil) }\end{array}$ & $\begin{array}{l}\text { Exchangeable } \\
\text { magnesium } \\
\text { (me/100g soil) }\end{array}$ & $\begin{array}{c}\text { Exchangeable } \\
\text { potassium } \\
(\mathrm{me} / 100 \mathrm{~g} \text { soil })\end{array}$ & $\begin{array}{c}\text { Total carbon } \\
(\%)\end{array}$ & $\begin{array}{c}\text { Total nitrogen } \\
(\%)\end{array}$ \\
\hline $\begin{array}{l}\text { Area excluded from live- } \\
\text { stock grazing for eight } \\
\text { years }\end{array}$ & 8.24 & 0.10 & 17.33 & 7.56 & 0.59 & 2.05 & 0.20 \\
\hline Continuous grazing area & 7.70 & 0.10 & 11.8 & 5.2 & 0.90 & 0.10 & 0.10 \\
\hline Dry season/calf grazing & 6.81 & 0.14 & 10.26 & 5.01 & 0.49 & 2.09 & 0.17 \\
\hline $\begin{array}{l}\text { Previous Maasai settle- } \\
\text { ments abandoned for } \\
\text { twenty years }\end{array}$ & 7.35 & 0.23 & 19.88 & 9.05 & 0.98 & 7.35 & 0.72 \\
\hline $\begin{array}{l}\text { Kruskal-Wallis } H \text { test } \\
\text { results }\end{array}$ & $\begin{array}{c}H(3)=13.52 \\
P=0.004\end{array}$ & $\begin{array}{l}H(3)=11.23 \\
P=0.010\end{array}$ & $\begin{array}{c}H(3)=12.03 \\
P=0.007\end{array}$ & $\begin{array}{c}H(3)=9.80 \\
P=0.020\end{array}$ & $\begin{array}{r}H(3)=9.37 \\
P=0.024\end{array}$ & $\begin{array}{c}H(3)=13.60 \\
P=0.003\end{array}$ & $\begin{array}{c}H(3)=14.84 \\
P=0.001\end{array}$ \\
\hline
\end{tabular}

factors shapes the biotic life (Westoby et al., 1989). While grazing alone does not determine the overall vegetation structure in rangelands, its effects can be adverse when rangelands are not well planned or managed. The dominance of Increaser I and Increaser II grass species (Tables 1 and 2) indicates that the rangeland has been under long-term stress from grazing. After eight years of exclusion from grazing, the rangeland has not fully recovered, showing only $21 \%$ Decreaser species, mostly Cenchrus ciliaris. Under heavy grazing, the species that are less resistant to grazing diminished, leaving more adaptable species that are less palatable to grazers. Cynodon dactylon, the dominant grass species, is associated with disturbed areas and is able to withstand heavy grazing through propagation by means of rhizomes and stolons (Oudtshoorn, 1992). Pennisetum sp. is relatively palatable during the wet season and progressively becomes hard and fibrous during the dry season, and is thus likely to have been avoided by grazers. The effects of continuous grazing in the continuous grazing area were evident due to the significantly lower frequencies and counts of perennial grasses and the exceptionally high proportion of bare ground. Similarly, the study of Allen et al. (1995) showed an increase in perennial species after six years of grazing exclusion in semiarid rangelands of Central Otago New Zealand.

The area excluded from grazing and that under seasonal grazing had higher grass biomass than those continually grazed ones. The grass height was $8-10$ times more in the area excluded from grazing and in the dry season livestock grazing area than in the continuous grazing area. By comparison, after sixteen years of exclusion from grazing, the amount of standing aboveground biomass doubled in the steep seasonally-dry pastoral lands of Southern Island, New Zealand (McIntosh and Allen, 1998).

As expected, the sites under continuous grazing conditions had the highest soil erosion potential, and the area excluded from grazing for eight years had the lowest. The percentage of bare ground on a site increased with grazing pressure (Milton et al., 1994; Robertson, 1996). Continuous grazing within the Maasai rangelands has led to loss of vegetation, with long-term implications for the health of the rangelands. The forage potential of the continuous grazing area was about 10 times less than that in both the area excluded from grazing for eight years and the dry season grazing area. As grazing pressure increased, the Decreaser grass species declined, leaving Increaser I and Increaser II species of low forage. The results from Yeo (2005) showed that plant composition, indicators of soil erosion, ground cover and vegetation cover improved in the enclosure site, compared to adjacent unenclosed sites.

There were different values for soil properties across the different treatments. The previously settled Maasai area and the area excluded from grazing for eight years tended to have the highest levels of soil nutrients, $\mathrm{pH}$ and exchangeable calcium. Changes in soil properties might arise from the indirect effects of grazing, such as soil erosion (McIntosh and Allen, 1998), nutrient accumulation through livestock dung in areas settled by pastoralists (Augustine, 2003) and soil enrichment by litter accumulation and subsequent decomposition (Berliner and Kioko, 2000). The lack of differences among soil properties between sites could be due to the slow rates of change in soil prop- 
erties over time (Marrs et al., 1989). The chemical composition and rate of decomposition of plant residues are important determinants of nitrogen and calcium accumulation in the soil (Whalen et al., 2003).

The area excluded from grazing may have gained nutrients from leaf decomposition, as there was minimal removal through large herbivore defoliation and minimal soil loss through erosion due to high vegetation cover. Similar studies showed that extremely degraded lands in Eastern Cape, South Africa had less organic carbon and organic matter than moderately degraded areas (Neary et al., 1999; Oluwole and Sikhalazo, 2008). Under heavy grazing, rangelands showed declines in soil carbon and nitrogen (He et al., 2011).

Calcium, which declined in the continuous grazing area, is one of the important exchangeable cations in semiarid soils for stabilizing soil $\mathrm{pH}$ (Berliner and Kioko, 2000). The soil $\mathrm{pH}$ was high in the area excluded from grazing for eight years and the previously settled Maasai areas, which was likely due to the high calcium level from decomposed plant organic matter. In the previous Maasai settlements, the calcium level might have been enriched by ash deposits from fire used within the settlements. Shifting livestock enclosures (Bomas) within the landscape has an important role in restructuring vegetation management through nutrient concentration (Muchiru et al., 2003).

\section{References}

Allen R B, Wilson J B, Mason C R. 1995. Vegetation change following exclusion of grazing animals in depleted grassland, Central Otago, New Zealand. Journal of Vegetation Science, 6(5): 615-626.

Augustine D J. 2003. Long-term, livestock-mediated redistribution of nitrogen and phosphorus in an East African savanna. Journal of Applied Ecology, 40(1): 137-149.

Berger D J. 1993. Wildlife Extension: Participatory Conservation by the Maasai of Kenya. Nairobi: African Centre for Technology Studies (ACTS).

Berliner D, Kioko J. 2000. The effect of long-term mowing and ungulate exclusion on grass species composition and soil nutrient status on the Athi-Kapiti plains, central Kenya. African Journal of Range Forage Science, 16(2-3): 62-70.

Botha J O. 1999. A resource management plan for the Lewa Wildlife Conservancy in the Meru District of the central highlands of Kenya. MSc. Thesis South Africa: University of Pretoria.

Bransby D, TaintonN M. 1977. The disc pasture meter: possible implication in grazing management. Proceedings of Grassland Society of

\section{Conclusion and recommendations}

Excluding an area from grazing for eight years did not significantly change the grass biomass relative to the dry season grazing area. These findings emphasize the role of regulated grazing in maintaining productivity of semiarid rangelands. The decline in soil erosion potential, the increase in grass biomass, forage potential and soil nutrients in the site excluded from grazing showed the potential of enclosure plots in the rehabilitation of highly degraded rangelands. It is likely that most of the areas have enough seed bank and would gradually recover with minimal or no grazing pressure. Previous homestead settlements are important nutrient concentration areas, so they should be taken into account when planning rangeland grazing strategies within rangelands. In the face of diminishing extensive grazing systems, as well as changing land tenure and land use, adaptive measures should be adopted to mitigate rangeland degradation.

\section{Acknowledgments}

This research was funded by the United States Fish and Wildlife Service and Cleveland MetroPark Zoo. Logistical and technical support came from the School for Field Studies-summer 2008 students and Moi University. This manuscript was greatly improved by the comments from two anonymous reviewers.

South Africa, 12: 115-118.

Burnsilver S, Mwangi E. 2007. Beyond group ranch subdivision: collective action for livestock mobility, ecological viability, and livelihoods. Washington DC: International Food Policy Research Institute.

Campbell D, Gichohi H, Mwangi A, et al. 2000. Land use conflict in Kajiado District, Kenya. Land use Policy, 17: 337-348.

Galt D, Molinar F, Navarro J, et al. 2000. Grazing capacity and stocking rate. Rangelands, 22(6): 7-11.

Graham O. 1989. A land divided: the impact of ranching on a pastoral society. Ecologist, 19 (5): 184-185.

He N P, Zhang Y H, Yu Q, et al. 2011. Grazing intensity impacts soil carbon and nitrogen storage of continental steppe. Ecosphere, 2(1): $1-10$.

Katampoi K, Genga G, Mwangi M, et al. 1990. Kajiado District Atlas. Kajiado: ASAL Programme.

Marrs R H, Rizand A, Harrison A F. 1989. The effects of removing sheep grazing on soil chemistry, above-ground nutrient distribution, 
and selected aspects of soil fertility in long-term experiments at Moor House National Nature Reserve. Journal of Applied Ecology, 26(2): 647-661.

McIntosh P D, Allen R B. 1998. Effect of enclosure on soils, biomass, plant nutrients, and vegetation, on unfertilized steep lands, upper Waitaki District, South Island, New Zealand. Journal of Ecology, 22(2): 209-217.

Mentis M S. 1981. Evaluation of the wheel-point and step-point methods of veld condition assessment. Proceedings of Grassland Society of South Africa, 16: 89-94.

Milton S J, Dean W R J, Du Plessis M A, et al. 1994. A conceptual model of arid rangeland degradation. Bioscience, 44(2): 707-718.

Morgan R P C. 1995. Soil Erosion and Conservation, $2^{\text {nd }}$ ed. Essex: Longman Group.

Muchiru A, Western D, Reid R S. 2003. The role of abandoned settlements in restructuring plant and wildlife communities, Amboseli Kenya. In: Allsopp N, Palmer A R, Milton S J, et al. Proceedings of the VIIth International Rangeland Congress, Durban, South Africa, July 26-August 1. South Africa: Document Transformation Technologies.

Musembi D K. 1986. The seasonal climate of rangelands. In: Hansen R M, Woie B M, Child R D. Range Development and Research in Kenya. Proceedings of a Conference, Agricultural Resource Center, Edgerton College, Njoro, Kenya, April 1-5, 1986. Morrilton: Winrock International Institute for Agriculture Development.

Neary D G, Klopatek C C, DeBano L F, et al. 1999. Fire effects on below ground sustainability: a review and synthesis. Forest Ecology Management, 122(1-2): 51-71.

Oba G, Post E, Syvertssen P O, et al. 2000. Bush cover and range condition assessments in relation to landscape and grazing in southern Ethiopia. Landscape Ecology, 15(6): 535-546.

O'Connor T G, Pickett G A. 1992. The effects of grazing history on the herbaceous composition: population structure and seed banks of some African savanna grasslands. Journal of Applied Ecology, 29(1): $247-260$.

Oluwole F A, Sikhalazo D. 2008. Land degradation in a reserve in
Eastern Cape of South Africa: soil properties and vegetation cover. Scientific Research and Essay, 3(3): 111-119.

Oudtshoorn F V. 1992. Guide to Grasses of South Africa. Pretoria: Briza Publications.

Owen-Smith N. 1999. The animal factor in veld management: implications of selective patters of grazing. In: Tainton N D. Veld Management in South Africa. Pietermaritzburg: University of Natal Press, 129-130.

Pratt D J, Gwynne M D. 1978. Rangeland Management and Ecology in East Africa. London: Hodder and Stoughton.

Robertson E. 1996. Impacts of Livestock Grazing on Soils and Recommendations for Management. California: California Native Plant Society.

Skarpe, C. 1992. Dynamics of savanna ecosystems. Journal of Vegetation Science 3(3): 293-300.

Trollope W S W. 1990. Development of a technique for assessing veld condition in the Kruger National Park using key grass species. Journal of Grassland Society of South Africa, 7(1): 46-51.

Trollope W S W, Trollope L A. 1999. Report of assessment of range condition and the fire of the savanna vegetation on the LEWA Downs Wildlife Conservancy, Kenya-1998. Alice: University of Fort Hare.

Western D, Wright R M. 1994. The background to community based conservation. In: Western D, Wright R M. Natural Connections: Perspectives in Community-based Conservation. Washington DC: Island Press, 1-14.

Westoby M B H, Walker, Noy-Meir I. 1989. Opportunistic management for rangelands not at equilibrium. Journal of Range Management, 42(4): 266-274.

Whalen J K, Willms W D, Dormaar J F. 2003. Soil carbon, nitrogen and phosphorus in modified rangeland communities. Journal of Range Management, 56(6): 665-672.

Yeo J J. 2005. Effects of grazing exclusion on rangeland vegetation and soils, east central Idaho. Western North American Naturalist, 65(1): 91-102. 